\title{
How enzymes are adsorbed on soil solid phase and factors limiting its activity: A Review**
}

\author{
Rahul Datta ${ }^{*}$, Swati Anand ${ }^{2}$,Amitava Moulick ${ }^{3}$, Divyashri Baraniya ${ }^{4}$, Shamina Imran Pathan ${ }^{5}$, \\ Klement Rejsek, Valerie Vranova ${ }^{1}$, Meenakshi Sharma ${ }^{6}$, Daisy Sharma ${ }^{7}$, Aditi Kelkar ${ }^{8}$, and Pavel Formanek ${ }^{1}$ \\ ${ }^{1}$ Department of Geology and Soil Science Faculty of Forestry and Wood Technology Mendel University 61300 Brno, Czech Republic \\ ${ }^{2}$ Department of Chemistry and Biochemistry, Brigham Young University, Provo, Utah, United States \\ ${ }^{3}$ Central European Institute of Technology, Brno University of Technology, Brno, Czech Republic \\ ${ }^{4}$ Department of Agrifood Production and Environmental Sciences, University of Florence, Piazzale delle Cascine, Florence, Italy \\ ${ }^{5}$ Department of Agricultural Sciences Mediterranean University of Reggio Calabria Feo di Vito Reggio Calabria, Italy \\ ${ }^{6}$ Department of Botany Daulat Ram College University of Delhi, India \\ ${ }^{7}$ RKGIT, Dr. A.P.J. Abdul Kalam Technical University, Lucknow, India \\ ${ }^{8}$ Northeastern University, Boston, Massachusetts, United States
}

Received January 19, 2017; accepted April 7, 2017

A b s t r a c t. A majority of biochemical reactions are often catalysed by different types of enzymes. Adsorption of the enzyme is an imperative phenomenon, which protects it from physical or chemical degradation resulting in enzyme reserve in soil. This article summarizes some of the key results from previous studies and provides information about how enzymes are adsorbed on the surface of the soil solid phase and how different factors affect enzymatic activity in soil. Many studies have been done separately on the soil enzymatic activity and adsorption of enzymes on solid surfaces. However, only a few studies discuss enzyme adsorption on soil perspective; hence, we attempted to facilitate the process of enzyme adsorption specifically on soil surfaces. This review is remarkably unmatched, as we have thoroughly reviewed the relevant publications related to protein adsorption and enzymatic activity. Also, the article focuses on two important aspects, adsorption of enzymes and factors limiting the activity of adsorbed enzyme, together in one paper. The first part of this review comprehensively lays emphasis on different interactions between enzymes and the soil solid phase and the kinetics of enzyme adsorption. In the second part, we encircle various factors affecting the enzymatic activity of the adsorbed enzyme in soil.

K e y w o r d s: adsorption of protein, adsorbed enzyme, enzymatic activity, soil solid phase, enzymes in soil

*Corresponding author e-mail: rahulmedcure@gmail.com

**This work was created within the framework of the grant LD14020 'A new compounds of water soluble root exudates of Ambrosia artemisiifolia cultivated under different conditions', (2014-2016).

\section{INTRODUCTION}

The study on soil enzymatic activities has emerged to be a major research area in soil microbiology. This has been fostered by the need to understand the soil biological and chemical processes, as well as the catalysts and factors that foster or undermine these processes to enhance the soil productivity (Burns, 1982). Soil can be perceived as a living ecosystem through which numerous biochemical processes take place with the help of both intracellular and extracellular enzymes (Skujiņš and Burns, 1976). In line with this, Nannipieri et al. (2003) argue that soil is a dynamic and complex biological system, whose complete microbial community composition is yet to be fully established, and hence understanding the link between the microbial activities, the community structure, and the soil composition is crucial. As such, the soil microorganisms play a crucial role in mediating the biochemical processes to ensure nutrient cycling, which entails physicochemical, chemical, and biochemical reactions. Different researchers hold it that enzymes present in soil are often released from the dead cells of living organisms or excreted from the microorganisms within the soil (Skujiņš and Burns, 1976). Particularly, the extracellular enzymes often emanate from the death of animal and plant cells; these cells are associated with rapid reproduction. Further, the extracellular enzymes have been found to be remarkably stable with respect to soil biochemical processes, an aspect that is attributed to their humus and clay association. However, irrespective of the stability, the enzymatic activity is highly dependent on the ambience of the soil $\mathrm{pH}$ and temperature (Kedi et al., 2013).

(C) 2017 Institute of Agrophysics, Polish Academy of Sciences 
T a b l e 1. Classification of different amino acids

\begin{tabular}{|c|c|c|c|c|}
\hline \multirow{2}{*}{$\begin{array}{l}\text { Amino acid with } \\
\text { hydrophobic side chain }\end{array}$} & \multicolumn{2}{|c|}{ Amino acid with electrically charged side chain } & \multirow{2}{*}{$\begin{array}{l}\text { Amino acid with polar } \\
\text { uncharged side chain }\end{array}$} & \multirow{2}{*}{ Special cases } \\
\hline & Positive charge & Negative charge & & \\
\hline Alanine & Arginine & Aspartic Acid & Serine & Cysteine \\
\hline Valine & Histidine & Glutamic Acid & Threonine & Seleno Cysteine \\
\hline Isoleucine & Lysine & & Asparagine & Glycine \\
\hline Leucine & & & Glutamine & Proline \\
\hline \multicolumn{5}{|l|}{ Methionine } \\
\hline \multicolumn{5}{|l|}{ Phenylalanine } \\
\hline Tyrosine & & & & \\
\hline Tryptophan & & & & \\
\hline
\end{tabular}

At any given point in time, the soil enzymatic activity encompasses a wide array of activities, each of which is associated with different constituents, such as humic colloids, clay, cell debris, and different microorganisms (Burns, 1982). A crucial aspect associated with the soil biochemical activities is the process of the enzyme adsorption. Enzyme adsorption is a protein immobilization technique that takes advantage of the enzymecarrier physical interactions including the hydrogen bonds, the ionic interactions, and the van der Waal forces (Jesionowski et al., 2014). This comprehensive review is aimed at gaining a better understanding of the enzyme adsorption on the soil solid surface and factors that limit this process. The adsorption process, the driving forces, the adsorption isotherm and reversibility of adsorption, the enzyme immobilization and its catalytic properties, and the factors controlling enzyme adsorption have comprehensively been reviewed.

\section{GENERAL OVERVIEW}

Enzymes are essential constituents of biological systems. All chemical reactions that sustain life are catalysed by enzymes (McCord, 2000). Twenty-one different amino acids are attached together in one or more polypeptide chain to form an enzyme molecule (Atkins and Gesteland, 2000). These amino acids are glycine, alanine, valine, leucine, isoleucine, proline, 4-hydroxy proline, serine, threonine, aspartic acid, glutamic acid, asparagine, glutamine, lysine, arginine, histidine, phenylalanine, tyrosine, tryptophan, cysteine, and methionine (Atkins and Gesteland, 2000; Minervini et al., 2014). The above twenty-one amino acids are basically divided into four groups on the basis of polarity and charge (Campbell et al., 2006) (Table 1):

a) amino acid with a hydrophobic side chain,

b) amino acid with electrically charged side chain,

c) amino acid with a polar uncharged side chain,

d) special cases.

Enzymes are generally globular proteins (Koshland, 1963). The amino acid sequence in the polypeptide chain determines the enzyme structure. Like all proteins, enzymes are linear chains of amino acids that fold to produce a three-dimensional structure. The three-dimensional structure is a net result of all different intra-molecular interactions between segments within the enzyme molecule and its surroundings (Fitzsimons et al., 2007; Mulvihill and Donovan, 1987). The side chain of an amino acid present in the enzyme molecule varies its polarity. Some are hydrophobic while others are hydrophilic. As a result of different interactions, there are four levels of enzyme structures: primary, secondary, tertiary, and quaternary.

\section{ADSORPTION PROCESS}

The adsorption of enzymes on the soil solid phase is a quasi-reversible phenomenon with great significance. Adsorption can also stabilize enzymes leading to their resistance toward denaturation, compared to a free enzyme. However, the mechanism of the enzyme interaction with the soil surface is still unclear (Norde, 2008). The microbial life in the soil is influenced by adsorption of extracellular enzymes into the soil (Nannipieri et al., 2003). An abundant amount of silica $\left(\mathrm{SiO}_{2}\right)$ is present in soil and is responsible for different physicochemical interactions between enzymes and soil. The outer surface of amorphous silica is exposed to silanol groups ( $\mathrm{Si}-\mathrm{OH})$ and siloxane bridges (-Si-O-Si-). At pH above 3, these silanol groups lose the hydrogen ion and develop a negative charge. As a result, the outer surface of soil becomes negatively charged (Zhuravlev, 2000). Lysine and arginine are free i.e. not involved in intra-molecular interactions, and are thus available for electrostatic interactions with the silica surface (Karlin et al., 1994, Musafia et al., 1995).

\section{Forces involved in enzyme adsorption}

Different forces are responsible for enzyme adsorption on the soil surface, but only electrostatic attraction is responsible for the first contact between the enzyme and the soil surface (Andrade and Hlady, 1986; Fenoglio et al., 2011; Ikeda and Kuroda, 2011). Electrostatic attraction is due to the electrostatic force of attraction between 
a charged amino acid and a negative charge present on silica. Arginine, histidine, and lysine have an electrically positive charged side chain above $\mathrm{pH} 4$; hence, they are called basic amino acids. They are key amino acids responsible for electrostatic interactions with the electronegative silica surface. Haynes and Norde explained thermodynamically various interactions contributing to protein adsorption (Haynes and Norde, 1994). Different types of interactions take place between an enzyme and a soil solid surface such as Van der Waals forces, Lewis acid-base forces, and entropy-based effects such as hydrophobic interactions, conformational entropy, and restricted movements. In addition to the above forces, adsorption depends on forces within the helical structure of enzymes, which make them hard or soft.

\section{Deformation of enzyme on soil surface}

After being attached, the enzyme molecule undergoes structural deformations. Rigid and tightly coiled enzymes are not easily deformed on the soil surface and are less prone to adsorption. This structural deformation is due to the charged amino acid, which remains deep inside the helical structure of the enzymes (Secundo, 2013). Structural deformation is due to the conformation of an enzyme that belongs to free energy minimum in a solution state and is not necessary to have same free energy minimum conformation after being adsorbed on the soil surface. A greater contact surface area of the enzymes to the soil surface induces a gain in free energy. Hence, the enzymes tend to maximize their footprint through different conformational changes, as shown in different experimental works (Billsten et al., 1995; Giacomelli and Norde, 2001; Santore and Wertz, 2005). The extent to which an enzyme is deformed strictly depends upon its structure, as explained by hard and soft protein (Galkin and Vekilov, 1999; Norde, 2003, 2008; Norde and Giacomelli, 2000). Instrumental techniques like ATR-IR (Karlsson et al., 2005; Sharp et al., 2002) and CD spectroscopy provide direct information about the change in the secondary structure of the enzyme (Billsten et al., 1995; Karlsson et al., 2005; Vieira et al., 2009).

Intermolecular forces within the helical structure of enzymes are mainly responsible for deformation of the enzyme on a solid surface, which happens just after the enzyme touches the soil surfaces. The reaction of the enzyme at interfaces is a net result of various types of interactions between different components of the system, i.e., the enzyme molecules, the sorbent surface, and the solvent (water) molecules (Zoungrana et al., 1997). An enzyme with weak structure can deform easily. As a result, more electrically charged side chains are exposed to oppositely charged silanol groups $(\mathrm{Si}-\mathrm{OH})$ present on the soil surface. Because of more interactions, the enzyme structure is deformed, and the enzyme is able to spread to maximum on the soil surfaces.

Percentage participation of each of the different types of the above-explained interactions depends on the nature of the system. For enzymes with strong intermolecular interactions, structural rearrangements do not contribute significantly to the adsorption process. Such enzymes are easily adsorbed on hydrophobic surfaces; however, they can adsorb on hydrophilic surfaces only if they are electrostatically attracted (Krisdhasima et al. 1992, Norde, 1986, 2003).

Enzymes with relatively weak intramolecular interactions are adsorbed on the hydrophilic surface even under extremely unfavourable conditions, e.g. an electrostatically repelling surface. In such a case, structural rearrangements are the main driving force for adsorption (Krisdhasima et al., 1992; Malmsten, 1998; Norde, 2003).

\section{Adsorption kinetics}

Various steps of enzyme adsorption and desorption on the soil solid surface are shown in Fig. 1. They are:

step 1. transport of the enzyme toward soil surface for the bulk,

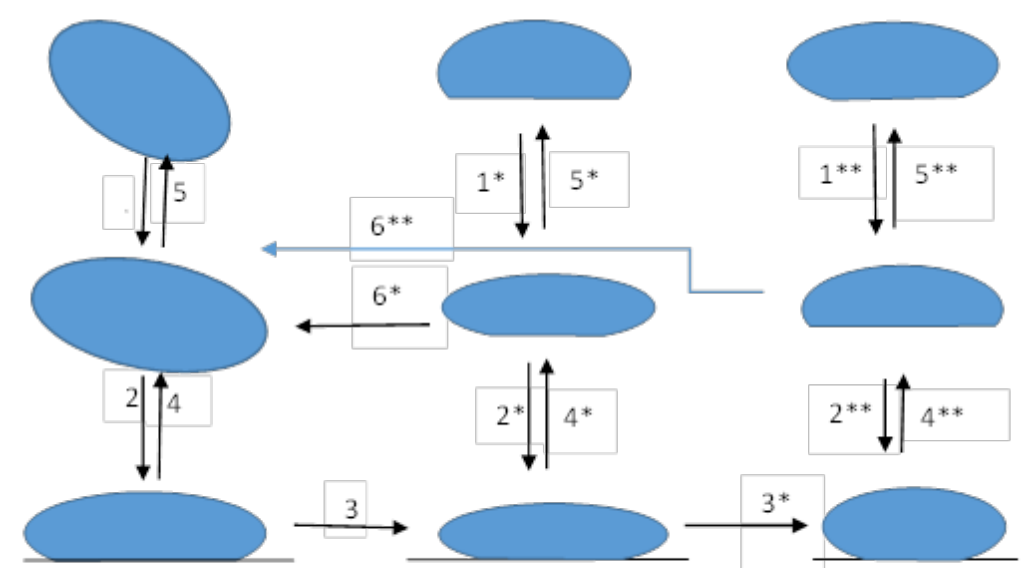

Fig. 1. Schematic presentation of the enzyme adsorption and desorption process. Explanation of step numbers in the text. 
step 2. deposition at the soil surface,

step 3. unfolding of the enzyme,

step 4. detachment of the enzyme from the soil surface,

step 5. transport away from the soil surface,

step 6. possible restructuring of the adsorbed enzyme.

An enzyme is transported near the soil surface by the convection process and its flow may be laminar or turbulent, but the last distance to the soil surface cannot be covered by the convection flow. The last step of attachment is always covered by diffusion. The enzyme and the adsorbing surface need to be dehydrated to overcome the hydrodynamic barrier just before the attachment of the enzyme to the soil surface (Kleijn and Norde, 1995). Before the attachment of the enzyme to the soil surface, the enzyme should be in proper spatial orientation towards the surface such that oppositely charged sites are in front of each other (Andrade and Hlady, 1986). Electrostatic attraction is the first as well as the rate-determining step. Without proper electrostatic attraction, there will be no initiation of adsorption irrespective of diffusion. The second step of the adsorption process depends on the degree of 'hardness-softness' of the enzyme or protein (Nannipieri et al., 2003). Various steps of adsorption and desorption are shown in Fig. 1.

The process of enzyme adsorption on the soil surface is broadly divided into two individual steps:

1. transport of the enzyme from the bulk to the soil surface, 2. deposition of the enzyme on the soil surface.

Both these steps have different limiting factors and different rate constants.

Step 1: transport of the enzyme from the bulk to the soil surface

As discussed above, the basic mechanisms of enzyme transport toward the soil solid surface are diffusion and convection (laminar or turbulent flow). Most transport processes take place through steady state convective diffusion driven by a fixed concentration gradient. In the steady state condition of laminar flow, the enzyme flux toward the soil solid surface is determined by transport coefficient $K_{m}$ (depends on hydrodynamic condition) and the difference in enzyme concentrations from the surface to the bulk.

The enzyme flux can be expressed as:

$$
J=K_{m}\left(C_{b}-C_{s}\right),
$$

where: $C_{b}$ and $C_{s}$ are the enzyme concentrations in the bulk solution and at the surface respectively, and $K_{m}$ is the transport coefficient.

Step 2: Deposition of the enzyme on the soil surface

Deposition of the enzyme on soil solid surface is directly proportional to the concentration gradient. It may be considered as a first order process.

The rate of change in the adsorbed amount is given by:

$$
\frac{d \Gamma}{d t}=K_{n}\left(C_{s}-C_{e q}\right)
$$

where: $\Gamma$ is the adsorbed mass per unit soil solid surface area and $K_{n}$ is the deposition rate constant. $C_{e q}$ is the concentration in the bulk solution corresponding to the equilibrium value for $\Gamma$, as given by the adsorption isotherm. Enzyme deposition is now determined by the rate constant $K_{n}$. Rate constant $\mathrm{Kn}$ decreases with an increase in $C_{s}$ until the equilibrium is reached. Thus, when the enzyme concentration at the soil solid surface is equal to the equilibrium concentration, the adsorption rate becomes zero.

\section{Relaxation of adsorbed layer}

After being attached to the soil solid surface, enzyme molecules start deforming from their native structure, which is termed as structural relaxation or unfolding of the enzyme. The unfolding of the enzyme is due to changes in the microenvironment of the enzyme. Structural relaxation is represented by step 3 in Fig. 1. Relaxation is difficult in the case of strong interaction between the enzyme and the soil surface. Structural relaxation leads to better spreading of enzyme molecules over the soil solid surface. Now the relaxed enzyme molecules are strongly attached and, therefore, more difficult to detach, which may result in structural heterogeneity in the adsorbed layer. During the initial stage of the adsorption process, the enzyme molecule gets sufficient area available for spreading. However, this is not the case for later stages of the adsorption process as the surface is already covered by enzyme molecules.

If the rate of spreading of the enzyme is faster than the rate of attachment, the shape of adsorbed enzyme molecules becomes flattened. However, when the enzyme flux increases, the adsorbed enzyme molecule acquires more globular conformation and, therefore, the adsorption mass per unit surface area increases.

\section{DRIVING FORCE}

The necessary driving force for the adsorption process is provided by negative Gibbs free energy $G$ at constant temperature and pressure and is given by the expression:

$$
\Delta G=\Delta H-T \Delta S<0,
$$

where: $H$ and $S$ are the enthalpies and the entropy of the system and where $\Delta$ indicates the change invoked by the adsorption process. The more negative value of $\Delta$, the higher the adsorption affinity.

The last and final step of the adsorption process is carried out by structural rearrangement of proteins, their surface polarity, reshuffling of distribution of charges at the interface, and dehydration of the surface (Haynes and Norde, 1994). During the structural rearrangement of an enzyme of the adsorbing soil surface, different intramolecular interactions become weak to maintain its secondary structure. There is a continuous increase in disorderliness or entropy of the enzyme, which favours the adsorption process.

Enzyme adsorption can occur easily on the polar hydrated surface because some non-polar part of the enzyme is present on its surface, which easily attracts the nonpolar part 
of the soil surface, but the strongest driving force is shown by dehydrated nonpolar absorbing surfaces (Micaêlo and Soares, 2007).

An electrical charge double layer forms at the soil surface and its counter charge remains present in the diffusion layer. This model is well described by Stern (Kirkwood, 1934). Electrostatic attraction between electrical double layers is formed on the surface of soil colloids and the enzyme molecule contributes to the negative value of Gibbs free energy.

\section{ADSORPTION ISOTHERM AND REVERSIBILITY OF ADSORPTION}

Adsorption data are typically presented as an adsorption isotherm. The measurement of the adsorption concentration versus the aqueous enzyme concentration gives an adsorption isotherm. Enzymes with globular structure form compact monolayer structure of molecules. In the case of an incomplete monolayer, a smaller plateau is obtained. This happens at a low concentration of the enzyme and depends on the orientation of the enzyme on the soil surface. The same enzyme has different patterns of orientation on soil surfaces at different concentrations. At first, the enzyme is attached to the adsorbed surface without any conformational change and this process is very fast. Later, the thickening of the adsorbed layer of enzymes occurs, and this is a slow process. The structure of the adsorbed layer depends on the kind of enzyme and type of surface. For example, if the shape of the enzyme is considered rectangular, two types of configuration may be present, end-on and side-on. At a low concentration of the enzyme, the side-on configuration is mainly found and, at a high concentration, the end-on configuration may be found (Andrade and Hlady, 1986; Kleijn and Norde, 1995; Nakanishi et al., 2001).

\section{ENZYME IMMOBILIZATION AND ITS CATALYTIC PROPERTIES: $K_{m}$ AND $V_{\max }$}

Soil enzyme is immobilized by either adsorption to clay mineral or it can bind chemically to organic matter present in the soil (Theng, 1979; Ladd, 1985). An immobilized enzyme varies in catalytic properties due to its heterogeneous nature (Katchalski et al., 2006). Heterogeneous catalysis involves the following processes:

a) adsorption of reactants on the surface of the catalyst,

b) chemical reactions of the activated forms on the surface, c) desorption of the reaction products.

Adsorption of the substrate on the surface of the catalyst and desorption of reaction products are a diffusion phenomenon governed by laws of diffusion.

Several studies show that enzyme immobilization decreases its activity, for example, protease (Butler and Ladd, 1969), oxidoreductase (Pflug, 1980; Sarkarand Burns, 1984), phosphatase, and invertase (Malcolm and Vaughan, 1979), and alters the kinetic parameters. Immobilized enzymes have lower $V_{\max }$ and higher $K_{m}$, compared to a free counterpart, indicating that binding results in structural changes in enzyme molecules (Kiss et al., 1998; McLaren and Packer, 2006). The immobilized enzyme shows an increase in stability towards physical, chemical, and biological degradation (Sarkar and Burns, 1984). Factors that may be responsible for decreased activity of immobilized enzyme are:

a) conformational changes in enzyme structure upon immobilization on a solid support,

b) steric limitations of the substrate to penetrate and reach the enzyme active site,

c) diffusion limitation of the substrate from the bulk of the solution to the immobilized enzyme and product from the enzyme active site to the bulk of the solution.

The above three factors are mainly responsible for the change in the value of kinetic parameters of immobilized enzymes. Immobilization of the enzyme results in a significant decrease in $V_{\max }$ values and an increase in $K_{m}$ values of enzymes, compared to free enzyme. $V_{\max }$ values usually decrease after adsorption. Few studies have reported an increase in $V_{\max }$ after immobilization (Lei and $\mathrm{Bi}, 2007$ ), but $K_{m}$ values do not necessarily increase for all enzymes; they may increase or decrease depending upon the type of enzyme. Gianfreda proved experimentally that invertase and phosphatase decrease $V_{\max }$ and increase $K_{m}$ values, compared to free enzymes after adsorption on pure and dirty clay. However, an increase in both $V_{\max }$ and $K_{m}$ values was reported on all clay (Gianfreda, 2000; Gianfreda et al., 1991; Rao and Rani et al., 2000).

Enzyme immobilization is considered an important phenomenon because once immobilized, the enzyme is more resistant to inactivation and degradation to the extreme in situ soil conditions, and it has $90 \%$ catalytic activity of the native enzyme (Rani et al., 2000). The immobilized enzyme, which is easily removed from the reaction solution, can later be reused.

Michaelis-Menten parameters can best explain enzyme inactivation upon adsorption to soil solid surface. The $K_{m}$ value is the measure of the affinity of the enzyme for the substrate. Higher $K_{m}$ indicates lower affinity and vice versa. The $V_{\max }$ value describes maximum velocity of conversion of substrate to the product when all the enzyme active sites are saturated with the substrate. The $K_{m}$ and $V_{\max }$ can be useful parameters as they are independent of the enzyme concentration used (Schnell and Maini, 2003).

The Michaelis-Menten parameters can be simply aplied to enzyme substrate reactions for the free enzyme i.e. homogenous reactions. Apparent kinetic values are obtained in case the enzyme is bound to the soil solid surface i.e. heterogeneous catalysis with diffusion limitation reactions. Two different types of enzyme inhibition occur upon adsorption of the enzyme to the soil solid phase (Fig. 2):

a) competitive inhibition,

b) noncompetitive inhibition (Fig. 2). 
Competitive inhibition is reversible where the inhibitor competes with the substrate to bind to the same active site on the enzyme and vice versa. This may cause an increase in the $K_{m}$ value without change in $V_{\max }$

This type of enzyme inhibition is similar to the temporary binding of organic matter to the enzyme active site.

In noncompetitive inhibition, the molecule binds to an enzyme surface other than the active site resulting in some conformational changes in the enzyme, such that the $V_{\max }$ value decreases but the $K_{m}$ value remains the same (Fig. 2). This type of inhibition may be analogous to enzyme mineral or organic matter interaction.

Mixed inhibition occurs in those soil mineral and soil organic matter interactions that calculate Michaelis-Menten parameters. In most experiments, there is an increase in the $K_{m}$ value, indicating decreased affinity of the enzyme toward the substrate. A decrease in the $K_{m}$ value indicates an increase in enzyme-substrate affinity, which may occur due to the formation of an adsorption bond orientation, which causes enhanced active site accessibility to the substrate and increased enzymatic activity, mainly for montmorillonite.

\section{FACTORS CONTROLLING ENZYME ADSORPTION}

Enzyme adsorption is a very complex phenomenon and there are many internal and external parameters affecting enzyme adsorption on a solid surface. A few of them are: temperature, $\mathrm{pH}$, soil moisture, and concentration of dissolved ions.

\section{Temperature}

Temperature is a crucial factor whose effect on the adsorption environment cannot be underestimated. While there are contradicting reports on the specific degree of the temperature effect on enzyme adsorption, almost all researchers agree that a change in temperature bears a significant effect on the enzyme adsorption, though there are variations in the recorded values. In an experiment using Sigmacell 50 and Sigmacell 20 and enzyme acquired from T. viride, Kim et al. (1998) unveiled that the Sigmacell adsorption capacity increases with an increase in temperature. Ooshima et al. (1983) also concluded that enzyme adsorption increases with an increase in temperature in an experiment entailing the use of Avicel at 5 and $50^{\circ} \mathrm{C}$ to adsorb cellulases. Bonomo et al. (2006) report that protein structures are affected by an increment in temperature, thereby exposing the hydrophobic sections of the protein to the adjacent environment. This, in turn, enhances the enzyme adsorption. Lee (2014) found only a small change in enzyme adsorption in an experiment using Solka floc SW-40 at 4 and $50^{\circ} \mathrm{C}$ to adsorb cellulases. Similarly, Barker et al. (1992) found out that the adsorption rate increased to maximum when the temperature of the enzyme mixture was increased form 55 to $60^{\circ} \mathrm{C}$.

As observed, enzyme adsorption increases above room temperature. This increase in adsorption is due to structural rearrangements at a higher temperature. The kinetics of enzyme adsorption is directly affected by even a small change in temperature and thereby altering the equilibrium state and all other kinetics parameters. With the change in temperature, the diffusivity of enzymes towards the soil surface is also affected.

The adsorption rate is likely to be increased due to the rapid diffusivity of the enzyme towards the soil surface. Enthalpy gain is the main driving force responsible for enzyme adsorption. It comes from structural changes taking place in the enzyme molecule and release of salt and water molecule from the surface (Andrade and Hlady, 1986; Malmsten, 1998; Norde, 1986; Ramsden, 1995). Hence, enzyme adsorption increases at higher temperatures (Koutsoukos et al., 1983; Norde, 1986).

\section{pH}

The soil $\mathrm{pH}$ is a crucial factor responsible for controlling a wide array of microbial processes. A change in the soil $\mathrm{pH}$ may result in altered hydrophobicity of the soil solid surface, which in turn may significantly affect the enzymatic activities. It is crucial to note that different enzymes operate best at different $\mathrm{pH}$ levels. A study by Bezerra and Dias (2005) entailing the adsorption of cellulases QM 9414 on Sweco 270, Solka Floc SW 20, and Avicel PH 102 at $30^{\circ} \mathrm{C}$ with a $\mathrm{pH}$ of 3.8 to 5.5 unveiled that as the $\mathrm{pH}$ increased from 4.8 to 5.5 , the enzyme adsorption decreased. This is seemingly contradicting to the findings by Tomme et al. (1990) who experimented on enzyme adsorption using Trichoderma reesei cellulases and concluded that 4.8 to 8.5 is the optimum $\mathrm{pH}$ for enzymatic hydrolysis. On the same note, an experiment by Kyriacou et al. (1988) using Solka floc BW-40 and fractionated $T$. reesei cellulases unveiled that even with an increase in the $\mathrm{pH}$ from 3 to 7 , the maximum adsorption at 5 and $50^{\circ} \mathrm{C}$ was the same.

Soil $\mathrm{pH}$ is a very important parameter for the progression of soil biochemical reactions. Soil $\mathrm{pH}$ has a direct effect on interfacial attraction. The electrostatic behaviour of the enzyme molecule is determined by the $\mathrm{pH}$ of the surroundings. When $\mathrm{pH}$ is equal to the isoelectric point of the enzyme, the numbers of negative and positive charges are balanced, resulting in the net neutral molecule. Hence, $\mathrm{pH}$ determines the electrostatic state of enzymes. Different enzymes have a different isoelectric point. At isoelectric $\mathrm{pH}$, the net charge on enzymes remains neutral. At low $\mathrm{pH}$, the net electric charge on the enzyme is positive whereas, at high $\mathrm{pH}$, the net charge is negative. Minimum repulsive forces are expected at isoelectric point allowing a thicker layer of the adsorbed enzyme on the soil surface. However, maximum adsorption is observed at the isoelectric point. Hence, it can be asserted that the isoelectric point denotes the maximum adsorption (Bremer et al., 2004; Demanèche et al., 2009; Sethuraman and Belfort, 2005). 


\section{Soil moisture}

Soil water stress occurs seasonally almost in all soils. Drying of soil can result in a decrease or complete cessation of enzyme activity. Many studies have been done on the impact of soil water stress on microbial communities. In most of the studies, enzyme activity was analysed (Zelles et al., 1991). Enzyme adsorption at the soil solid surface can result in inactivation caused by conformational changes due to an increased concentration of the enzyme at soil-water interface (Durán and Esposito, 2000). Prokaryotes living in the thin water layer surrounding the soil particles are very sensitive to water depletion. Changes in soil as a result of drying are more physical than chemical. Enzyme activity decreases with a decrease in the size of soil organic matter and increases with a decrease in soil mineral matter (Killham, 1994). Chemical changes are usually very small (Wu and Brookes, 2005) and occur within 1-2 months of soil drying. Many cycles of drying and rewetting alter soil water potential creating osmotic stress (Halverson et al., 2000), and it leads to microbial death unless they remain dormant until more favourable conditions occur (Schimel et al., 2007).

\section{Concentration of dissolved ions}

The concentration of dissolved ions has a significant effect on enzyme adsorption. Increasing salt concentrations result in decreased enzyme adsorption at the interface until a complete suppression at high concentrations is reached. This is because of reduced attractive electrostatic interaction between the positively charged enzymes and negatively charged surfaces by charge screening (Jones and O'Melia, 2000). Further, high ionic concentration causes significant interference with the weak ionic bonds in the enzymes. It is crucial to note that enzymes comprise a non-protein called co-factor and a protein that is made of chains of various amino acids. As such, the enzymes are characterized by inter and intra-molecular bonds which keep the molecules in position (Liu and Zhu, 2010). The interference caused by the high ionic concentration leads to dysfunctional bonds between the amino-acids group. This, in turn, leads to denaturation, an aspect that entails the loss of the shape by an enzyme. Essentially, if an enzyme structural shape is compromised, it becomes challenging for it to react and accept substrate, and hence the adsorption rate is significantly affected (Liu and Zhu, 2010).

Earlier it has been known that an increased salt concentration supports the precipitation of colloidal substances. This is due to the absorption of water by salt ions. This phenomenon is known as a salting out effect. Hofmeister found that different salt ions have different ability to precipitate proteins from a solution, which leads to the concept of the Hofmeister series (Kunz et al., 2004). Kosmotropes are ions that promote protein precipitation leading to a cha- otropic effect. Chaotropic and kosmotropic effects are due to stabilization and destabilization of native conformations of proteins, which influence enzyme adsorption.

\section{KEY FACTORS AFFECTING THE ENZYMATIC ACTIVITY OF ADSORBED ENZYMES IN SOIL}

\section{Substrate diffusion}

Diffusion is an important process in the kinetics of rapid reactions in a solution. Diffusion may be the rate-limiting step in very rapid reactions and such reactions are termed as diffusion-limited reactions. Diffusion is also an important step for heterogeneous reactions occurring at the solid surface. Limitation of substrate diffusion towards the enzyme adsorbed on the soil surface could be one of the key factors for the decrease in enzyme activity (Arrio-Dupont and Béchet, 1989; Bille et al., 1989; Douzou and Petsko, 1984; Konecny and Voser, 1977). Enzyme substrate reactions are zero order kinetic. Enzyme activity is maximum on the soil surface; hence, the rate of the reaction is maximum near the surface. The concentration of the substrate remains lowest adjacent to the surface relative to the bulk of the solution. The concentration gradient develops from the bulk of the solution to the soil surface (Bille et al., 1989; Ku and Lentrichia, 1989). There can be three different situations if the diffusion is: slow, equal and fast relative to substrate consumption at the soil surface.

If diffusion is slow, it is the rate-limiting step and the reaction is diffusion limitation. If diffusion is equal to substrate consumption at the soil surface, then the steady state will eventually be established such that the rate of diffusion of the substrate in the unstirred layer (Nernst diffusion layer) equals the consumption rate of the substrate. In the case of faster diffusion, the reaction will be enzyme limited. In most of the soil conditions, the enzymatic activity is usually low, compared to the large surface area of soil (Datta et al., 2014).

It should be noted that for a reaction to be diffusionlimited, it is necessary for the step following the initial combination of the enzyme and substrate to be faster than diffusion apart from the reactants; therefore, diffusion-limited reactions are indirect evidence for a conformational change following the combination of the enzyme and substrate.

\section{Orientation effects}

Enzymes are small asymmetric complex molecules of different shapes such as elliptical, rod-like, heart-like, or Y-shaped, etc. Enzymes can rotate freely in the solution whereas on the surface different enzymes adapt certain orientation. The orientation decides which part of the enzyme will face towards the soil surface and which part will expose towards the bulk solution. Orientation is an imperative factor for enzymatic activity. Any improper orientation can decrease or completely inhibit enzymatic activity. Spatial enzyme immobilization on a solid surface increases its activity and stability (Brady and Jordaan, 2009; Cao, 
2005; Hanefeld et al., 2009; Tischer and Wedekind, 1999). Orientation on the solid surface can be characterized by 'side-on' or 'end-on'. These orientations are best explained by Lu et al. (1998) and Su et al. (1998).

The selective orientation of the enzyme on the electronegative soil surface is expected if a higher density of a positively charged amino acid is present at this face. In this regard, the following cases are expected:

- if the more positive face is not varying with a change in $\mathrm{pH}$ during the reaction process, and the active site is present on this face, then complete inhibition of the enzyme could be expected. No inhibition of activity is observed if the active site is on the opposite side;

- if a more positive charge faces changes with increased $\mathrm{pH}$, an alkaline shift is observed. If the active site is present on this face, then an increase in optimal enzyme activity is observed due to more exposure of the active site towards the substrate.

Similarly, the acid shift is observed if the polarity of the enzyme changes due to a decrease in $\mathrm{pH}$. Apart from explained cases, there are many situations where the active site is neither completely masked nor completely exposed. Enzymes of hard proteins are less prone to $\mathrm{pH}-$ dependent modification of conformation and enzymes with higher dipole moment are more likely to show preferential orientation.

\section{Temperature}

Temperature is also one of the factors that strongly affect and control soil enzyme activity. It can influence enzyme kinetics, stability, substrate affinity, and enzyme production. Thermal stability of an adsorbed enzyme is often increased in comparison to that of a free enzyme. Enzymes retain their functionality and selectivity after being adsorbed on the soil surface. Adsorption increases thermal stability two to three times when compared to the same enzyme in a solution (Nannipieri et al. 1982).

Most of the studies conducted for determining the effect of temperature on enzymatic activity have been done in lab conditions. Very few studies are done in field conditions by soil warming treatment. Studies done in field conditions show very little to no change in enzyme activity (Allison and Treseder, 2008). Temperature and climate change affect the activity of the adsorbed enzyme in different ways, which it is difficult to predict; most commonly, it is observed that the activity increases up to some optimum level (Wallenstein and Weintraub, 2008). Soil microbes may decrease their secretions after a certain level of warming (Allison, 2005). The rate of enzyme denaturation also increases with warming (Wallenstein et al., 2012).

\section{Enzyme-clay mineral interaction}

Like proteins, enzymes show a strong affinity towards different mineral surfaces. Clay plays an important role in the adsorption of the enzyme surface catalysed process involving enzymatic protein and enzyme immobilization in soil (Boyd and Mortland, 1990).

Extracellular enzymes are physically and chemically adsorbed on clay mineral surfaces. Some studies put forward that electrostatic interaction dominates protein mineral interaction (Ding and Henrichs, 2002; Servagent-Noinville et al., 2000). The mechanism of enzyme-clay mineral interaction is a complex phenomenon because enzymes are made up of amino acids with varied properties, e.g. they can be hydrophilic, hydrophobic, positively, negatively and neutrally charged. The shape of the amino acid may change in response to various environmental conditions.

Adsorption of an amino acid monomer and dimer shows significant relations between the net charge present on it and the charge density present on the mineral surface. No such relation is seen in the case of protein or enzyme adsorption on the clay mineral surface. Therefore, electrostatic force cannot be considered as a dominating factor in controlling enzyme or protein adsorption although the surface of many minerals is negatively charged and proteins contain some amount of negative or positive charge, due to their amphiphilic nature (Zimmerman et al., 2004).

Hydrophobic interactions and a decrease in the free energy of the enzyme due to conformational changes are the most predominant mechanism of protein adsorption on the clay mineral surface. This mechanism can also explain the adsorption of proteins on hydrophobic surfaces under unfavourable electrostatic conditions.

The amount of an enzyme adsorbed on the clay and its property to form a complex with the clay mineral rigorously depend on many factors such as the nature and properties of the enzyme and clay (Naidja, 1995; Theng, 1979). Gianfreda proved experimentally that there is no significant relation between the surface area of clay mineral and the amount of enzyme adsorbed (Gianfreda et al., 1991; Greco et al., 1982).

Change in the kinetic properties of the enzyme is observed upon adsorption to the mineral surface. The activity of the enzyme is reduced on adsorption, and the extent of reduction depends on factors such as the type of enzyme, clay mineral, and pH (Gianfreda et al., 1991, 1992; Violante et al., 1999). The list of changes in enzymatic activity that has been observed upon adsorption to various adsorbents is shown in Table 2.

Different responses of adsorbed enzyme on clay mineral surface were attributed to different:

- arrangements held by the enzymes on clays, and

- kinds of electrostatic interactions occurring between enzyme molecules and binding sites on clay. 
T a b l e 2. Changes in enzyme activity following clay mineral interaction

\begin{tabular}{|c|c|c|c|}
\hline Adsorbent & Enzyme & Activity change & Reference \\
\hline Ca-montmorillonite & Peroxidase & 0 to -69 & Lozzi et al., 2001 \\
\hline Na-montmorillonite & Peroxidase & -88 to -99 & Lozzi et al., 2001 \\
\hline Ca-montmorillonite & Catalase & -81 to -99 & Calamai et al., 2000 \\
\hline Kaolinite & Tyrosinase & 0 to -75 & Claus and Filip, 1988 \\
\hline Kaolinite & Acid phosphatase & -64 & Gianfreda and Bollag, 1994 \\
\hline Montmorillonite & Acid phosphatase & -68 & Gianfreda and Bollag, 1994 \\
\hline Montmorillonite complex & Peroxidase & 0 & Gianfreda and Bollag, 1994 \\
\hline $\mathrm{Al}(\mathrm{OH}) \mathrm{x}$ & Invertase & -94 to -99 & Gianfreda et al., 1991 \\
\hline $\mathrm{Al}(\mathrm{OH}) \mathrm{x}$-montmorillonite & Invertase & -89 to -95 & Gianfreda et al., 1991 \\
\hline Na-montmorillonite & Invertase & -88 to -96 & Gianfreda et al., 1991 \\
\hline $\mathrm{Al}(\mathrm{OH}) \mathrm{x}$-montmorillonite & Urease & -49 to -67 & Gianfreda et al., 1992 \\
\hline Na-montmorillonite & Urease & -41 & Gianfreda et al., 1992 \\
\hline Goethite & Acid phosphatase & -32 & Huang et al., 2005 \\
\hline Kaolinite & Acid phosphatase & -43 & Huang et al., 2005 \\
\hline Ca-montmorillonite & Arylsulphatase & -52 & Hughes and Simpson, 1978 \\
\hline Kaolinite & Arylsulphatase & -18 & Hughes and Simpson, 1978 \\
\hline Goethite & Glucosidase & 0 to 40 & Quiquampoix, 1987 \\
\hline Kaolinite & Glucosidase & -13 to -100 & Quiquampoix, 1987 \\
\hline Kaolinite & Glucosidase & 0 to -88 & Quiquampoix, 1987 \\
\hline Na-montmorillonite & Glucosidase & -35 to -100 & Quiquampoix, 1987 \\
\hline Al hydroxide & Acid phosphatase & -55 & Rao and Gianfreda, 2000 \\
\hline Al hydroxide & Phosphatase & -55 & Rao et al., 2000 \\
\hline $\mathrm{Al}(\mathrm{OH}) \mathrm{x}$-montmorillonite & Phosphatase & -42 & Rao et al., 2000 \\
\hline Na-montmorillonite & Phosphatase & -80 & Rao et al., 2000 \\
\hline Allophane & Glucose oxidase & -52 & Ross and McNeilly, 1972 \\
\hline Ca-montmorillonite & Glucose oxidase & -77 & Ross and McNeilly, 1972 \\
\hline Illite & Glucose oxidase & -21 & Ross and McNeilly, 1972 \\
\hline Kaolinite & Glucose oxidase & -17 & Ross and McNeilly, 1972 \\
\hline Elledge clay & Alkaline phosphatase & -75 & Tietjen and Wetzel, 2003 \\
\hline Elledge clay & Glucosidase & 55 & Tietjen and Wetzel, 2003 \\
\hline Elledge clay & Protease & -82 to 82 & Tietjen and Wetzel, 2003 \\
\hline Montmorillonite & Glucosidase & 50 & Tietjen and Wetzel, 2003 \\
\hline Montmorillonite & Protease & -100 & Tietjen and Wetzel, 2003 \\
\hline
\end{tabular}


Adsorption of the enzyme on the solid soil surface may be modified by the presence of metal oxides and hydroxides such iron aluminium and manganese (Rao et al., 2000). The presence of aluminium hydroxide on montmorillonite surfaces resulted in lower activity for invertase, tyrosinase, and urease, whereas the same metal oxide increases the activity of phosphatase (Gianfreda et al., 1991, 1992; Naidja and Huang, 1996; Rao et al., 1996).

\section{Enzyme organic matter interactions}

Apart from clay minerals, enzymes can also be adsorbed on soil humus (Ladd and Butler, 1975). The enzyme soil organic matter interaction plays an important and vital role in controlling enzymatic activity, especially in soil comprising high organic matter content (Pflug, 1982). In soils with higher sand and organic matter, enzyme organic matter interactions are of greater significance in regulating soil enzyme activity and stability than the enzyme mineral interaction (Table 3).

Many mechanisms have been proposed for the formation of the enzyme-humus complex such as:

- covalent attachment of the enzyme to soil humic substances,

- physical entrapment in humus,

- hydrogen bonding, and

- ionic bonding (Burns, 1982).

T a b l e 3. Changes in enzyme activity following organic matter interaction

\begin{tabular}{|c|c|c|c|}
\hline Adsorbent & Enzyme & Percentage change in activity & Reference \\
\hline 2,4,6-Trimethylphenol & Laccase & 0 to -30 & Cañas et al., 2007 \\
\hline Acetosyringone & Laccase & -10 to -50 & Canas et al., 2007 \\
\hline Acetovanillone & Laccase & -70 or +50 & Canas et al., 2007 \\
\hline Benzoquinone & Pronase & -32 to -96 & Rowell et al., 1973 \\
\hline \multirow[t]{8}{*}{ Ferulic acid } & Laccase & -30 or +80 & Canas et al., 2007 \\
\hline & Acid phosphatase & -20 to -65 & Allison, 2006 \\
\hline & Catalase & 100 & Serban and Nissenbaum, 1986 \\
\hline & Glucosaminidase & -75 to -90 & Allison, 2006 \\
\hline & Glucosidase & -70 to -100 & Allison, 2006 \\
\hline & Malate dehydrogenase & -16 to -57 & Pflug and Ziechmann, 1981 \\
\hline & Papain & +88 to +160 & Butler and Ladd, 1969 \\
\hline & Papain & +49 to +226 & Freeman et al., 2004 \\
\hline \multirow[t]{7}{*}{ Humic acid } & Peroxidase & +18 to +125 & Serban and Nissenbaum, 1986 \\
\hline & Phosphatase & +10 to +100 & Boavida and Wetzel, 1998 \\
\hline & Polyphenol oxidase & -35 to -70 & Allison, 2006 \\
\hline & Pronase & -40 to -73 & Butler and Ladd, 1969 \\
\hline & Pronase & -25 to -35 & Ladd and Butler, 1969 \\
\hline & Tyrosinase & -5 to +19 & Ruggiero and Radogna, 1988 \\
\hline & Urease & -10 to -35 & Allison, 2006 \\
\hline p-coumaric acid & Laccase & -85 or +250 & Cañas et al., 2007 \\
\hline Phenolic compound & Chitinase & -22 & Freeman et al., 2004 \\
\hline Syringaldehyde & Laccase & 0 to -50 & Canas et al., 2007 \\
\hline Tannic acid & Acid phosphatase & -49 to -93 & Rao et al., 2000 \\
\hline Vanillin & Laccase & -50 to -60 & Canas et al., 2007 \\
\hline
\end{tabular}


Sometimes non-polar interaction is also found between the enzyme and natural organic matter.

Soil organic matter cannot be thoroughly extracted out except humic substances because enzymes remain covalently bound to soil and, therefore, they become inseparable from the soil. Due to this, it is impossible to separate the enzyme humic acid complex by any purification methods (Rao et al., 1996, 2000).

Enzymes react chemically with lignin, phenols, tannins, humic acid, and quinones to form complex organic matter components of soil. In this regard, strong $\mathrm{pH}$-dependent bonds such as covalent, electrovalent, and hydrogen are known to occur. There are several studies on extraction and purification of the enzyme humic acid complex, but none of them has shown any single type of association. In fact, a different combination of mechanisms has been proposed by different groups. Such combinations are covalent bonding, hydrogen bonding ion exchange, and physical entrapment methods (Ruggiero and Radogna, 1988).

Many groups have shown the impact of the electrostatic force on the enzyme-organic matter complex. Inorganic cation can be used to inactivate the complexed enzyme. Use of sodium pyrophosphate in extracting soil organic matter bound extracellular enzyme was put forward by Ceccanti et al. (1978) and Nannpieri et al. (1982). They also suggested that large fractions of enzymes are covalently bound to the humic surface than electrostatic interaction (Mayaudon and Sarkar, 1975; Pflug, 1982). The correlation between enzyme activity in soil and extracted organic carbon or nitrogen suggests binding of enzymes to the humic material (Nannipieri et al., 1980).
The porous structure of humic acid facilitates inward diffusion of the small substrate molecule and outward diffusion of the product molecule, but at the same time, the movement of larger molecules is restricted. Hydrophobic interactions are mainly responsible for enzyme humic acid interaction (Tan et al., 2009; Zang et al., 2000, 2001). It is observed that enzyme activity of the organic matter bound enzyme is highly specific for the particular enzyme. After interaction with organic matter, some enzyme activities increase while others decrease. Deactivation occurs due to the orientation of the enzyme active site by intermolecular forces. Soil porosity is also an important factor affecting enzymatic activity. Soil sieved through fine size mesh shows greater enzymatic activity than sieved through bigger mesh size sieve. This is due to exposure of a greater enzyme-adsorbed soil surface area to the substrate (Datta et al., 2014).

\section{RECENT TOOLS AND TECHNIQUE FOR STRUCTURAL DETERMINATION OF IMMOBILIZED ENZYME AND ITS SUPPORT}

The three-dimensional orientation of an immobilized enzyme is crucial for its activity and stability. Immobilization is the net result of various conformational changes that occur within and outside the enzyme surface. Immobilization could cause altered enzyme activity (Schröder et al., 2006). The formation of individual biomolecules and their orientation on surfaces can easily be monitored by different microscopic and spectroscopic techniques.

Fourier transformed infrared spectroscopy (FTIR) is a widely used technique to analyse immobilized enzyme structure. FTIR can easily determine changes occurring in

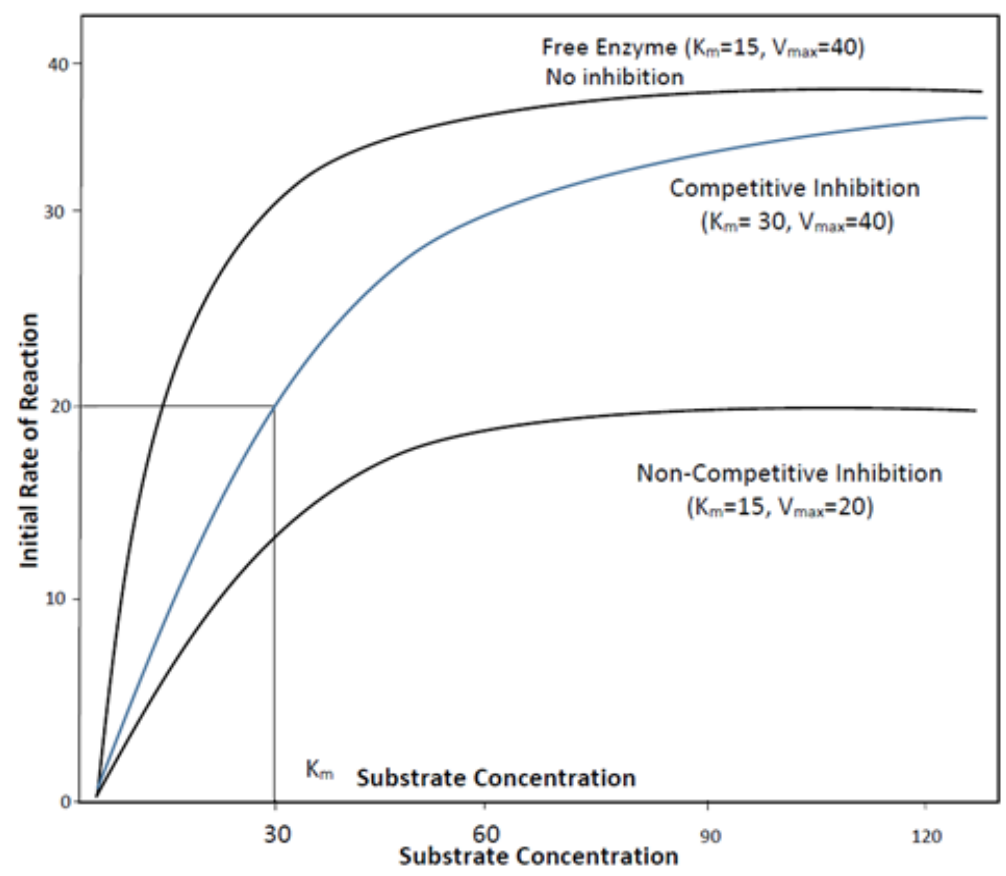

Fig. 2. Michaelis-Menton plot showing predicted kinetics change with 3 different types of enzyme inhibition. 
the secondary and tertiary structure of the enzyme upon immobilization, the formation of the hydrogen bond, and other enzyme surface interactions (Barth, 2007; Carlsson et al., 2014; Yang et al., 2015). The Fourier transformed technique has been used to observe the structure of many enzymes such as lipase, protease, and glucose oxidase (Gole et al., 2001; Portaccio et al., 2014).

Circular dichroism (CD) spectroscopy serves as a powerful method in structural determination and enzyme immobilization studies. CD elucidates the structure information of enzyme solid surface interaction (Carlsson et al., 2014; Thyparambil et al., 2015). CD spectroscopy is an alternative to FTIR spectroscopy in the characterization of an immobilized enzyme. Many immobilized enzymes obtained with different methods have been analysed using CD. Modification in the enzyme secondary structure after immobilization has also been observed by CD spectroscopy (Barth, 2007; Thyparambil et al., 2015; Verma et al., 2013).

Atomic-Force Microscopy (AFM) is a unique microscopic technique that can visualize enzyme molecules at a single molecular level with high accuracy (da Silva et al., 2015). It can visualize the enzyme surface, being attached to support (Gole et al., 2001; Hanefeld et al., 2009). Surfaceinduced changes due to enzyme surface interaction and changes due to enzyme interaction are easily visualized by AFM (da Silva et al., 2015). Hence, the technique is widely used in many surface-based protein interactions (da Silva et al., 2015; Gole et al., 2001).

Electron microscopy visualizes an immobilized enzyme at nanometer level resolution with limited information about the internal structure. Scanning electron microscope (SEM) and field emission scanning electron microscope (FESEM) are highly applied techniques for morphological characterization of the enzyme and surface (Kröger et al., 1999, Reátegui and Aksan, 2009). FESEM helps to visualize the very small change in enzyme morphology upon immobilization (Sang and Coppens, 2011). Transmission electron microscopy (TEM) also provides good structural morphology, but it provides only a two-dimensional surface structure (Lei et al., 2006).

Raman spectroscopy is also potentially a strong technique to analyse enzyme structure in dried or frozen solution samples (Thyparambil et al., 2015; Xiao et al., 2012). There is increasing use of Raman spectroscopy to characterize immobilized enzyme. (Ash and Vincent, 2012; Xiao et al., 2012).

Latest technique such as Foster resonance energy transfer (FRET) measurements (Mohamad et al., 2015), solid-state nuclear magnetic resonance spectroscopy (NMR) (Noureddini and Gao, 2007), Trp/Tyr fluorescence measurements (da Silva et al., 2015), and TOF-secondary ion mass spectrometry (Thyparambil et al., 2015) are gathering strength and more advancement are expected in near future.

\section{RECAPITULATION}

Enzyme adsorption on the soil solid phase is a complex phenomenon; different forces acting together at the same time make it more complex. Enzyme organo-mineral relationship directly affects enzymatic activity in any soil. Although continuous research has been done on enzyme interactions on soil solid phase over the past decades, which helps us in advancing our understanding on enzyme adsorption, it is still unclear how an enzyme behave when it comes in contact with the soil surface. Further advancement in technology is necessary to understand in depth the enzyme organo-mineral interaction. More advanced spectroscopic techniques can help in determining changes occur in the tertiary structure of enzyme after adsorption.

Many studies on adsorption of proteins on solid surfaces focus on enzymatic activity in soil, but none of them emphasize on adsorption with soil perspective. In this regard, this review chiefly endeavours to simplify the process of enzyme adsorption on soil surfaces, clarifying further the effect of enzyme adsorption on enzymatic activity. Needless to say, enzyme adsorption of on soil surfaces must not be omitted while discussing the enzymatic activity. Furthermore, this article is obtrusive as it has exhaustively reviewed all important publications on protein adsorption on the soil surface and enzymatic activity done separately before compiling these two relevant aspects together in one paper.

Conflict of interest: I declare that there is no conflict of interest between authors.

\section{REFERENCES}

Allison S.D., 2005. Cheaters, diffusion and nutrients constrain decomposition by microbial enzymes in spatially structured environments. Ecology Letters, 8, 626-635.

Allison S.D. and Treseder K.K., 2008. Warming and drying suppress microbial activity and carbon cycling in boreal forest soils. Global Change Biology, 14, 2898-2909.

Andrade J. and Hlady V., 1986. Protein adsorption and materials biocompatibility: a tutorial review and suggested hypotheses. In Biopolymers/Non-Exclusion HPLC, 1-63. Springer.

Arrio-Dupont M. and Béchet J.-J., 1989. Diffusion-limited kinetics of immobilized myosin ATPase. Biochimie, 71, 833-838.

Atkins J.F. and Gesteland R.F., 2000. Translation: The twentyfirst amino acid. Nature, 407, 463-464.

Baujard-Lamotte L., Noinville S., Goubard F., Marque P., and Pauthe E., 2008. Kinetics of conformational changes of fibronectin adsorbed onto model surfaces. Colloids and Surfaces B: Biointerfaces, 63, 129-137.

Bille V., Plainchamp D., Lavielle S., Chassaing G., and Remacle J., 1989. Effect of the microenvironment on the kinetic properties of immobilized enzymes. European J. Biochemistry, 180, 41-47.

Billsten P., Wahlgren M., Arnebrant T., McGuire J., and Elwing H., 1995. Structural changes of T4 lysozyme upon adsorption to silica nanoparticles measured by circular dichroism. J. Colloid Interface Sci., 175, 77-82. 
Boavida M.J. and Wetzel R.G., 1998. Inhibition of phosphatase activity by dissolved humic substances and hydrolytic reactivation by natural ultraviolet light. Freshwater Biology, 40, 285-293.

Brady D. and Jordaan J., 2009. Advances in enzyme immobilisation. Biotechnology Letters, 31, 1639-1650.

Bremer M.G., Duval J., Norde W., and Lyklema J., 2004. Electrostatic interactions between immunoglobulin ( $\mathrm{IgG})$ molecules and a charged sorbent. Colloids and Surfaces A: Physicochemical and Engineering Aspects, 250, 29-42.

Butler J.H. A. and Ladd J.N., 1969. The effect of methylation of humic acids on their influence on proteolytic enzyme activity. Australian J. Soil Res., 7, 263-268.

Calamai L., Lozzi I., Stotzky G., Fusi P., and Ristori G.G., 2000. Interaction of catalase with montmorillonite homoionic to cations with different hydrophobicity: effect on enzymatic activity and microbial utilization. Soil Biology Biochemistry, 32, 815-823.

Campbell R., Heidaran M., Spargo C., Wilkins J., and Haaland P., 2001. Peptides promoting cell adherence, growth and secretion. Google Patents.

Cañas A.I., Alcalde M., Plou F., Martínez M.J., Martínez Á.T., and Camarero S., 2007. Transformation of polycyclic aromatic hydrocarbons by laccase is strongly enhanced by phenolic compounds present in soil. Environmental Science Technology, 41, 2964-2971

Cao L., 2005. Immobilised enzymes: science or art? Current Opinion in Chemical Biology, 9, 217-226.

Claus H. and Filip Z., 1988. Behaviour of phenoloxidases in the presence of clays and other soil-related adsorbents. Appl. Microbiol. Biotechnol., 28, 506-511.

Datta R., Vranová V., Pavelka M., Rejšek K., and Formánek P., 2014. Effect of soil sieving on respiration induced by lowmolecular-weight substrates. Int. Agrophys., 28, 119-124.

Demanèche S., Chapel J.-P., Monrozier L. J., and Quiquampoix H., 2009. Dissimilar $\mathrm{pH}$-dependent adsorption features of bovine serum albumin and $\alpha$-chymotrypsin on mica probed by AFM. Colloids and Surfaces B: Biointerfaces, 70, 226-231.

Douzou P. and Petsko G.A., 1984. Proteins at work: "stopaction" pictures at subzero temperatures. Adv. Protein Chem., 36, 245-361.

Evers F., Reichhart C., Steitz R., Tolan M., and Czeslik C., 2010. Probing adsorption and aggregation of insulin at a poly (acrylic acid) brush. Physical Chemistry Chemical Physics, $12,4375-4382$.

Fenoglio I., Fubini B., Ghibaudi E.M., and Turci F., 2011. Multiple aspects of the interaction of biomacromolecules with inorganic surfaces. Advanced Drug Delivery Reviews, 63, 1186-1209.

Freeman C., Ostle N.J., Fenner N., and Kang H., 2004. A regulatory role for phenol oxidase during decomposition in peatlands. Soil Biology and Biochemistry, 36, 1663-1667.

Galkin O. and Vekilov P.G., 1999. Direct determination of the nucleation rates of protein crystals. J. Physical Chemistry, B, 103, 10965-10971.

Giacomelli C.E., and Norde W., 2001. The adsorption-desorption cycle. Reversibility of the BSA-Silica system. J. Colloid Interface Sci., 233, 234-240.

Gianfreda L. and Bollag J.-M., 1994. Effect of Soils on the Behavior of Immobilized Enzymes. Soil Science Society America J., 58. 1672-1681.

Gianfreda L., Rao M.A., and Violante A., 1991. Invertase $\beta$-fructosidase): Effects of montmorillonite, AL-hydroxide and $\mathrm{AL}(\mathrm{OH}) \mathrm{x}$-montmorillonite complex on activity and kinetic properties. Soil Biology Biochemistry, 23, 581-587.

Gianfreda L., Rao M.A., and Violante A., 1992. Adsorption, activity and kinetic properties of urease on montmorillonite, aluminium hydroxide and $\mathrm{AL}(\mathrm{OH}) \mathrm{x}$-montmorillonite complexes. Soil Biology Biochemistry, 24, 51-58.

Gianfreda L., Rao M. A., and Violante A., 1995. Formation and activity of urease-tannate complexes affected by Aluminum, Iron, and Manganese. Soil Science Society America J., 59, 805-810.

Hanefeld U., Gardossi L., and Magner E., 2009. Understanding enzyme immobilisation. Chemical Society Reviews, 38, 453-468

Haynes C.A. and Norde W., 1994. Globular proteins at solid/ liquid interfaces. Colloids Surfaces B: Biointerfaces, 2: 517-566.

Huang Q., Liang W., and Cai P., 2005. Adsorption, desorption and activities of acid phosphatase on various colloidal particles from an Ultisol. Colloids and Surfaces B: Biointerfaces 45, 209-214.

Hughes J.D. and Simpson G.H., 1978. Arylsulphatase clay interactions. II. The effect of kaolinite and montmorillonite on arylsulphatase activity. Aust. J. Soil Res., 16, 35-40.

Ikeda T. and Kuroda A., 2011. Why does the silica-binding protein "Si-tag" bind strongly to silica surfaces? Implications of conformational adaptation of the intrinsically disordered polypeptide to solid surfaces. Colloids Surfaces B: Biointerfaces, 86, 359-363.

Jones K.L. and O'Melia C.R., 2000. Protein and humic acid adsorption onto hydrophilic membrane surfaces: effects of $\mathrm{pH}$ and ionic strength. J. Membrane Sci., 165, 31-46.

Karlin S., Zuker M., and Brocchieri L., 1994. Measuring residue association in protein structures possible implications for protein folding. J. Molecular Biol., 239, 227-248.

Karlsson M., Ekeroth J., Elwing H., and Carlsson U., 2005. Reduction of irreversible protein adsorption on solid surfaces by protein engineering for increased stability. J. Biological Chemistry, 280, 25558-25564.

Kirkwood J.G., 1934. Theory of solutions of molecules containing widely separated charges with special application to zwitterions. J. Chemical Physics, 2, 351-361.

Kleijn J. and Norde W., 1995. The adsorption of proteins from aqueous solution on solid surfaces. Heterogeneous Chemistry Reviews, 2, 157-172.

Konecny J. and Voser W., 1977. Effects of carrier morphology and buffer diffusion on the expression of enzymatic activity. Biochimica et Biophysica Acta (BBA)-Enzymology, $485,367-378$

Koshland D., 1963. Correlation of structure an function in enzyme action. Science, 142, 1533-1541.

Koutsopoulos S., Tjeerdsma A.-M., Lieshout J.F., van der Oost J., and Norde W., 2005. In situ structure and activity studies of an enzyme adsorbed on spectroscopically undetectable particles. Biomacromolecules, 6, 1176-1184.

Koutsoukos P., Norde W., and Lyklema J., 1983. Protein adsorption on hematite ( $\alpha$-Fe 2 O 3) surfaces. J. Colloid Interface Sci., 95, 385-397.

Krisdhasima V., McGuire J., and Sproull R., 1992. Surface hydrophobic influences on $\beta$-lactoglobulin adsorption kinetics. J. Colloid Interface Sci., 154, 337-350. 
Ku C.-A. and Lentrichia B.B., 1989. Effects of diffusion limitation on binding of soluble ligand to avidin-coupled latex particles. J. Colloid Interface Sci., 132, 578-584.

Kunz W., Henle J., and Ninham B.W., 2004. 'Zur Lehre von der Wirkung der Salze'(about the science of the effect of salts): Franz Hofmeister's historical papers. Current Opinion in Colloid Interface Sci., 9, 19-37.

Kyriacou A., Neufeld R.J., and MacKenzie C.R., 1988. Effect of physical parameters on the adsorption characteristics of fractionated Trichoderma reesei cellulase components. Enzyme and Microbial Technology, 10, 675-681.

Ladd J. and Butler J., 1975. Humus-enzyume systems and synthetic, organic polymer-enzyme analogs. Soil Biochemistry, 4, 143-193.

Ladd J.N., 1985. Soil Enzymes. In: Soil Organic Matter and Biological Activity, Springer Science + Business Media.

Lee S.-I., 2014. Spatial Mathematics: Theory and Practice through Mapping by Sandra Lach Arlinghaus and Joseph J. Kerski. Boca Raton, FL, CRC Press, 300 pp. Geographical Analysis 46: 456-458.

Lei C., Shin Y., Magnuson J.K., Fryxell G., Lasure L.L., Elliott D.C., Liu J., and Ackerman E.J., 2006. Characterization of functionalized nanoporous supports for protein confinement. Nanotechnology, 17, 5531-5538.

Lei Z. and Bi S., 2007. The silica-coated chitosan particle from a layer-by-layer approach for pectinase immobilization. Enzyme and Microbial Technology, 40, 1442-1447.

Liu H. and Zhu J.Y., 2010. Eliminating inhibition of enzymatic hydrolysis by lignosulfonate in unwashed sulfite-pretreated aspen using metal salts. Bioresource Technology, 101, 9120-9127.

Lozzi I., Calamai L., Fusi P., Bosetto M., and Stotzky G., 2001. Interaction of horseradish peroxidase with montmorillonite homoionic to $\mathrm{Na}^{+}$and $\mathrm{Ca}^{2+}$ : effects on enzymatic activity and microbial degradation. Soil Biology and Biochemistry, 33, 1021-1028.

Lu J.R., Murphy E.F., Su T.J., Lewis A.L., Stratford P.W., and Satija S.K., 2001. Reduced protein adsorption on the surface of a chemically grafted phospholipid monolayer. Langmuir, 17, 3382-3389.

Lu J.R., Su T.J., and Thomas R.K., 1998. Binding of surfactants onto preadsorbed layers of bovine serum albumin at the silica-water interface. J. Physical Chemistry, B, 102, 10307-10315.

Malmsten M., 1998. Formation of adsorbed protein layers. J. Colloid and Interface Sci., 207, 186-199.

Marfo T.D., Datta R., Lojkova L., Janous D., Pavelka M., and Formanek P., 2015. Limitation of activity of acid phosphomonoesterase in soils. In: Amino Acids, Springer Wien, Wien, Austria.

Mayaudon J. and Sarkar J., 1975. Laccases de Polyporus versicolor dans le sol et la litiere. Soil Biology Biochemistry, 7, 31-34.

McCord J.M., 2000. The evolution of free radicals and oxidative stress. American J. Medicine, 108, 652-659.

McGuire J., Wahlgren M.C., and Arnebrant T., 1995. Structural stability effects on the adsorption and dodecyltrimethylammonium bromide-mediated elutability of bacteriophage T4 lysozyme at silica surfaces. J. Colloid Interface Sci., 170, 182-192.
Micaêlo N.M. and Soares C.M., 2007. Modeling hydration mechanisms of enzymes in nonpolar and polar organic solvents. Febs J., 274, 2424-2436.

Minervini G., Masiero A., Potenza E., and Tosatto S.C., 2015. Structural protein reorganization and fold emergence investigated through amino acid sequence permutations. Amino Acids, 47, 147-152.

Mulvihill D. and Donovan M., 1987. Whey proteins and their thermal denaturation-a review. Irish J. Food Sci. Technol., 43-75.

Musafia B., Buchner V., and Arad D., 1995. Complex salt bridges in proteins: statistical analysis of structure and function. J. Molecular Biology, 254, 761-770.

Nakanishi K., Sakiyama T., and Imamura K., 2001. On the adsorption of proteins on solid surfaces, a common but very complicated phenomenon. J. Bioscience Bioengineering, 91, 233-244.

Nannipieri P., Ascher J., Ceccherini M., Landi L., Pietramellara G., and Renella G., 2003. Microbial diversity and soil functions. European J. Soil Sci., 54, 655-670.

Nannipieri P., Ceccanti B., Conti C., and Bianchi D., 1982. Hydrolases extracted from soil: their properties and activities. Soil Biology Biochemistry, 14, 257-263.

Norde W., 1986a. Adsorption of proteins from solution at the solid-liquid interface. Adv. Colloid Interface Sci., 25, 267-340.

Norde W., 1986b. The interfacial behavior of proteins in relation to their structural properties. In: Surfactants in Solution, Springer.

Norde W., 2003. Driving forces for protein adsorption at solid surfaces. Surfactant Science Series, 110, 21-43.

Norde W., 2008. My voyage of discovery to proteins in flatland... and beyond. Colloids Surfaces B: Biointerfaces, 61, 1-9.

Norde W. and Giacomelli C.E., 2000. BSA structural changes during homomolecular exchange between the adsorbed and the dissolved states. J. Biotechnology, 79, 259-268.

Pancera S., Gliemann H., Schimmel T., and Petri D., 2006. Adsorption behavior and activity of hexokinase. J. Colloid Interface Sci., 302, 417-423.

Pflug W., 1982. Effect of clay minerals on the activity of polysaccharide cleaving soil enzymes. Zeitschrift für Pflanzenernährung und Bodenkunde, 145, 493-502.

Quiquampoix H., 1987. A stepwise approach to the understanding of extracellular enzyme activity in soil II. Competitive effects on the adsorption of a $\beta$-d-glucosidase in mixed mineral or organo-mineral systems. Biochimie, 69, 765-771.

Ramsden J., 1995. Puzzles and paradoxes in protein adsorption. Chemical Society Reviews, 24, 73-78.

Rani A., Das M., and Satyanarayana S., 2000. Preparation and characterization of amyloglucosidase adsorbed on activated charcoal. J. Molecular Catalysis, B: Enzymatic, 10, 471-476.

Rao M.A., Gianfreda L., Palmiero F., and Violante A., 1996. Interactions of acid phosphatase with clays, organic molecules and organo-mineral complexes. Soil Science, 161, 751-760.

Rao M.A., Violante A., and Gianfreda L., 2000. Interaction of acid phosphatase with clays, organic molecules and organomineral complexes: kinetics and stability. Soil Biology Biochemistry, 32, 1007-1014. 
Reátegui E. and Aksan A., 2009. Structural Changes in Confined Lysozyme. J. Biomechanical Eng., 131: 074520-074520-4.

Ross D.J. and McNeilly B.A., 1972. Some influences of different soils and clay minerals on the activity of glucose oxidase. Soil Biology Biochemistry, 4, 9-18.

Rowell M.J., Ladd J.N., and Paul E.A., 1973. Enzymically active complexes of proteases and humic acid analogues. Soil Biology Biochemistry, 5, 699-703.

Ruggiero P. and Radogna V., 1988. Humic acids-tyrosinase interactions as a model of soil humic-enzyme complexes. Soil Biology Biochemistry, 20, 353-359.

Sang L.-C. and Coppens M.-O., 2011. Effects of surface curvature and surface chemistry on the structure and activity of proteins adsorbed in nanopores. Physical Chemistry Chemical Physics, 13, 6689-6698.

Santore M.M. and Wertz C.F., 2005. Protein spreading kinetics at liquid-solid interfaces via an adsorption probe method. Langmuir, 21, 10172-10178.

Sarkar J.M. and Burns R.G., 1984. Synthesis and properties of $\beta$-d-glucosidasephenolic copolymers as analogues of soil humic-enzyme complexes. Soil Biology Biochemistry, 16, 619-625.

Schimel J., Balser T.C., and Wallenstein M., 2007. Microbial stress-response physiology and its microbial stress-rewsponse physiology and its implications for ecosystem function. Ecology, 88, 1386-1394.

Schnell S. and Maini P.K., 2003. A century of enzyme kinetics: reliability of the KM and vmax estimates. Comments on Theoretical Biology, 8, 169-187.

Schröder M., Von Lieres E., and Hubbuch J., 2006. Direct quantification of intraparticle protein diffusion in chromatographic media. J. Physical Chemistry, B 110, 1429-1436.

Secundo F., 2013. Conformational changes of enzymes upon immobilisation. Chemical Society Reviews, 42, 6250-6261.

Serban A. and Nissenbaum A., 1986. Humic acid association with peroxidase and catalase. Soil Biology Biochemistry, $18,41-44$

Servagent-Noinville S., Revault M., Quiquampoix H., and Baron M.H., 2000. Conformational changes of bovine serum albumin induced by adsorption on different clay surfaces: FTIR analysis. J. Colloid and Interface Science, 221, 273-283.

Sethuraman A. and Belfort G., 2005. Protein structural perturbation and aggregation on homogeneous surfaces. Biophysical J., 88, 1322-1333.

Sharp J.S., Forrest J.A., and Jones R.A.L., 2002. Surface denaturation and amyloid fibril formation of insulin at model lipid-water interfaces. Biochemistry, 41, 15810-15819.

Skujiņš J., and Burns R.G., 1976. Extracellular enzymes in soil. CRC Critical Reviews in Microbiology, 4, 383-421.

Su T.J., Lu J.R., Thomas R.K., Cui Z.F., and Penfold J., 1998. The effect of solution $\mathrm{pH}$ on the structure of lysozyme layers adsorbed at the silica-water interface studied by neutron reflection. Langmuir, 14, 438-445.

Tan W.F., Koopal L.K., and Norde W., 2008. Interaction between humic acid and lysozyme, studied by dynamic light scattering and isothermal titration calorimetry. Environmental Sci. Technol., 43, 591-596.

Theng B.K.G., 1979. Preface. In: Developments in Soil Science. Scientific Publishing Company, Amsterdam, The Netherlands.
Thyparambil A.A., Wei Y., and Latour R.A., 2015. Experimental characterization of adsorbed protein orientation, conformation, and bioactivity. Biointerphases, 10, 019002.

Tietjen T. and Wetzel R., 2003. Extracellular enzyme-clay mineral complexes: Enzyme adsorption, alteration of enzyme activity, and protection from photodegradation. Aquatic Ecology, 37, 331-339.

Tischer W. and Wedekind F., 1999. Immobilized enzymes: methods and applications. In: Biocatalysis-from Discovery to Application, Springer.

Tomme P., Heriban V., and Claeyssens M., 1990. Adsorption of two cellobiohydrolases fromTrichoderma reesei to Avicel: Evidence for „exo-exo” synergism and possible "loose complex' formation. Biotechnology Letters, 12, 525-530.

Verma M.L., Naebe M., Barrow C.J., and Puri M., 2013. Enzyme immobilisation on amino-functionalised multiwalled carbon nanotubes: structural and biocatalytic characterisation. PloS one, 8, e73642.

Vieira E.P., Rocha S., Carmo Pereira M., Mohwald H., and Coelho M.A., 2009. Adsorption and diffusion of plasma proteins on hydrophilic and hydrophobic surfaces: effect of trifluoroethanol on protein structure. Langmuir, 25, 9879-9886.

Violante A., Arienzo M., Sannino F., Colombo C., Piccolo A., and Gianfreda L., 1999. Formation and characterization of $\mathrm{OH}-\mathrm{Al}$-humate-montmorillonite complexes. Organic Geochemistry, 30, 461-468.

Wallenstein M., Allison S.D., Ernakovich J., Steinweg J.M., and Sinsabaugh R., 2011. Controls on the temperature sensitivity of soil enzymes: a key driver of in situ enzyme activity rates. In: Soil enzymology, Springer.

Wallenstein M.D., Haddix M.L., Lee D.D., Conant R.T., and Paul E.A., 2012. A litter-slurry technique elucidates the key role of enzyme production and microbial dynamics in temperature sensitivity of organic matter decomposition. Soil Biology Biochemistry, 47, 18-26.

Wallenstein M.D. and Weintraub M.N., 2008. Emerging tools for measuring and modeling the in situ activity of soil extracellular enzymes. Soil Biology Biochemistry, 40, 2098-2106.

Wu J. and Brookes P.C., 2005. The proportional mineralisation of microbial biomass and organic matter caused by air-drying and rewetting of a grassland soil. Soil Biology Biochemistry, 37, 507-515.

Xiao Y., Stone T., Bell D., Gillespie C., and Portoles M., 2012. Confocal Raman microscopy of protein adsorbed in chromatographic particles. Analytical Chemistry, 84, 7367-7373.

Yang H., Yang S., Kong J., Dong A., and Yu S., 2015. Obtaining information about protein secondary structures in aqueous solution using Fourier transform IR spectroscopy. Nature Protocols, 10, 382-396.

Zang X., Nguyen R.T., Harvey H.R., Knicker H., and Hatcher P.G., 2001. Preservation of proteinaceous material during the degradation of the green alga Botryococcus braunii: a solid-state 2D $15 \mathrm{~N} 13 \mathrm{C}$ NMR spectroscopy study. Geochimica et Cosmochimica Acta, 65, 3299-3305.

Zang X., van Heemst J.D., Dria K.J., and Hatcher P.G., 2000. Encapsulation of protein in humic acid from a histosol as an explanation for the occurrence of organic nitrogen in soil and sediment. Organic Geochemistry, 31, 679-695. 
Zelles L., Adrian P., Bai Q.Y., Stepper K., Adrian M.V., Fischer K., Maier A., and Ziegler A., 1991. Microbial activity measured in soils stored under different temperature and humidity conditions. Soil Biology Biochemistry, 23, 955-962.

Zhuravlev L., 2000. The surface chemistry of Amorphous silica. Zhuravlev model. Colloids and Surfaces A: Physicochemical Engineering Aspects, 173, 1-38.
Zimmerman A.R., Goyne K.W., Chorover J., Komarneni S., and Brantley S.L., 2004. Mineral mesopore effects on nitrogenous organic matter adsorption. Organic Geochemistry, 35, 355-375.

Zoungrana T., Findenegg G.H., and Norde W., 1997. Structure, stability, and activity of adsorbed enzymes. J. Colloid Interface Sci., 190, 437-448. 